\title{
OBSERVATIONS OF HYBRID SAGE $X$ SHARP-TAILED GROUSE IN SASKATCHEWAN
}

\author{
DALE G. HJERTAAS, Wildlife Branch, Saskatchewan Environment and \\ Resource Management, 3211 Albert Street, Regina, SK. S4S 5W6
}

Sage Grouse have rarely been reported to hybridize with other grouse. Two Sage X Sharp-tailed Grouse hybrids were reported from Montana, ${ }^{1}$ the first description of hybridization between these species, and a Sage Grouse X Sharp-tailed Grouse hybrid was observed displaying on a Sage Grouse lek in North Dakota. ${ }^{4}$ A case of hybridization between Sage Grouse and Blue Grouse has also been described. ${ }^{5}$

In 1988 I observed hybrid Sage Grouse near Meyronne and south of Glentworth. I reported these observations as the first for Saskatchewan.

Meyronne Surveys conducted by the Wildlife Branch of what is now the Department of Environment and Resource Management have documented the decline of a small Sage Grouse population in Meyronne Community Pasture, just south of the village of Meyronne. Sage Grouse historically used 2 leks here on NW/3 and NE/4 of TWP 8-7W3.

Data on file summarizing the Meyronne Sharp-tailed Grouse spring survey record populations of two male Sage Grouse in 1975 (memo T. Weins to S. Barber, Wildlife Branch, 5 May 1977), nine males 2 May 1976 (D. Hjertaas), eight males 16\&29 April 1977 (T. Weins), five males and one female 26 April 1979 (R. Longmuir), four males 24 April 1980 (S. Barber), and four males 22 April 1981 (M. Hlady). The 1981 observa- tion was interesting because two of the Sage Grouse were displaying on a Sharp-tailed Grouse lek while the other two were about 300 metres from this lek which was approximately 600 metres from the former Sage Grouse lek. M. Hlady observed two male Sage Grouse displaying at this Sharp-tailed Grouse lek on 7 May 1982 and one displaying male Sage Grouse with 18 Sharp- tailed Grouse 3 May 1983. Surveys by R. Melinchuk (1984), K. Callelle (1985), T. Weins and F. Beek (1986), and D. Hjertaas (1987) failed to locate any Sage Grouse.

On 2 May 1988 I observed what was apparently the last "half" of a Sage Grouse at Meyronne, a hybrid male displaying at a Sharp-tailed Grouse lek. When I first observed this lek, at 5:50 a.m., 24 male Sharptailed Grouse were dancing vigorously. One female Sharp-tailed Grouse was also present as well as the hybrid. The hybrid showed many aspects of typical Sharp-tail lek behaviour. It paired off with a male Sharp-tail, stamped its feet, spread its tail in a fan and hooted. Its posture was similar to that of the displaying Sharp-tailed Grouse. I noted that the hoots had a much deeper tone than the Sharp-tailed Grouse.

The hybrid was significantly larger than a Sharp-tailed Grouse. Its bill had a slight but more noticeable curve than the Sharp-tailed Grouse and the bill tip was black. The base 


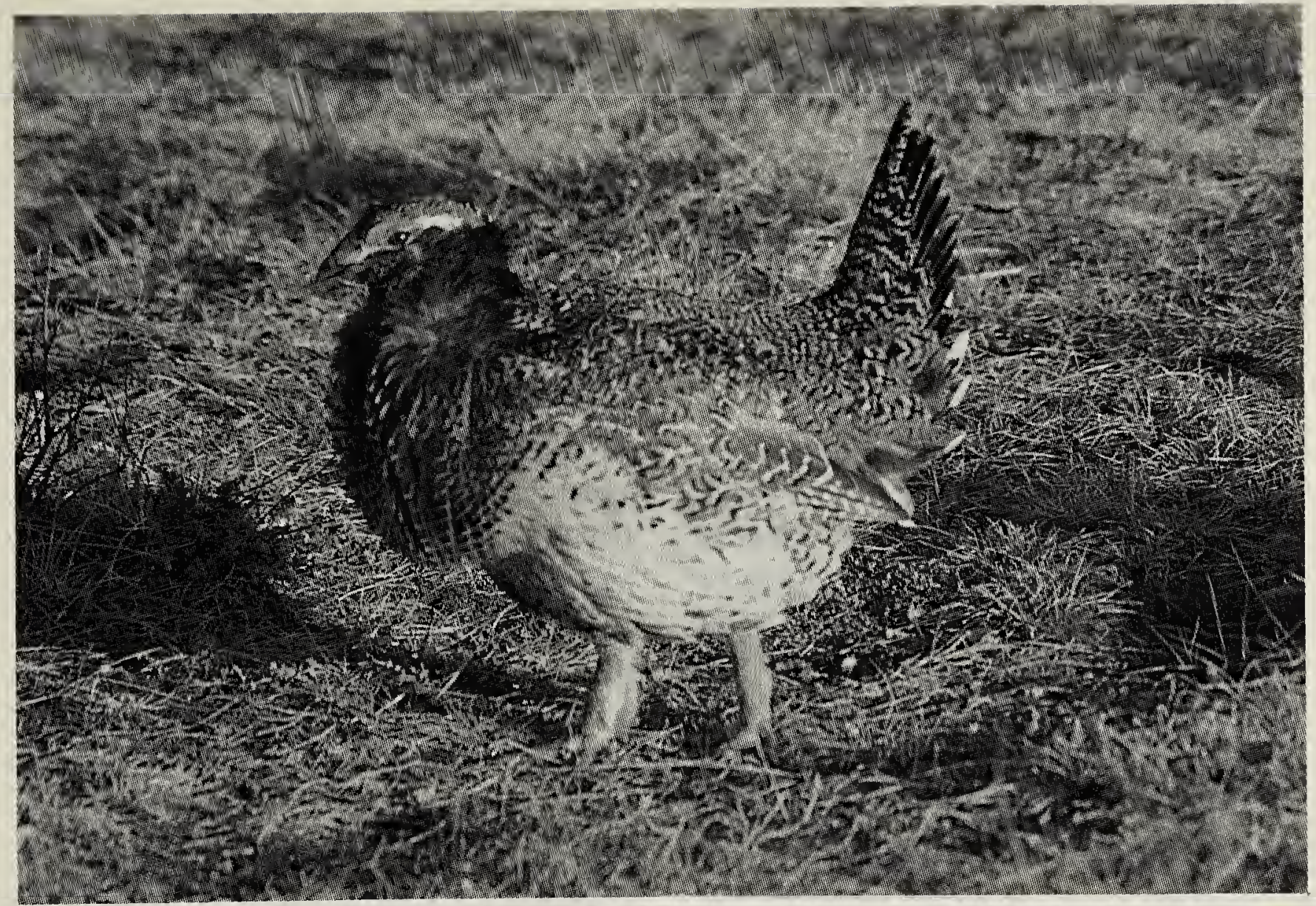

Dale Hjertaas

of the throat was black while the belly was light-coloured with a hint of the black belly of a Sage Grouse on the lower belly. Back coloration was similar to a Sharp-tailed Grouse and wings showed the white flecks of a Sharp-tailed Grouse. The chest had a big dark ruff containing air sacs. This ruff is analogous to the yellowish ruff of a Sage Grouse, but with longer brown feathers. When it erected this ruff the feathers along the neck stood up, giving the impression of two little horns. At a distance these made one think of the pinnae of the Greater Prairie Chicken but on closer inspection it is clear that these were erected neck feathers, there was no sign of separate long pinnae. The tail feathers, which he spread in a fan while displaying, were dark with a white tip when viewed from the front and appeared white and black when viewed from the rear. He had a yellow stripe over his eye. In addition he had two white lines on the head. One started just behind the eye, ran toward the back of the head and then curved down the neck. The other started at the base of the bill and ran parallel to the first.

I revisited the lek later in May with J. Brochu, and obtained a series of photos. I searched this and neighbouring leks the following year but found no sign of the hybrid.

This hybrid clearly shows marks of a Sage Grouse in its large air sacs and covering ruff, and in the tail. It shares these characters with the Sage Grouse/Sharp-tailed Grouse hybrid from North Dakota. ${ }^{4}$ It shows its Sharp-tailed Grouse ancestry in the white flecks in the wing, and whitish breast, with brown $V$ patterns along the edge.

The decline of the Meyronne Sage Grouse population from the recorded high of nine males in 1976 to 0.5 males in 1988 and then extinction may be due to habitat modification. When I first observed the population in 1976 | was surprised as the stands of Sage Brush in this pasture seemed marginal for Sage Grouse. 
T. Weins (memo to S. Barber, Wildlife Branch, 5 May 1977) noted that approximately $85 \%$ of the pasture had been broken and seeded to crested wheat grass. An unsigned note in the survey file indicates this conversion to crested wheat grass was apparently completed in the first part of the 1970s. Thus the quantity of sage brush on which the Sage Grouse depend may have originally been more extensive. Its disappearance could have caused the population decline. The area where the Sage Grouse were observed was one of the more extensive areas of native vegetation remaining in the pasture.

Glentworth In 1987 Harris, Weidl \& McAdam $^{2}$ reported a single male hybrid grouse on a Sage Grouse lek with 40 male Sage Grouse on 9 Twp 1-6W3 along Weatherald Creek. When observed on 17 April the hybrid was actively dancing near the centre of the lek and was continually chasing any male Sage Grouse which infringed upon its territory. The observers reported this as a Sage Grouse X Greater Prairie Chicken hybrid. This hybrid was still present with 27 male Sage Grouse when the lek was visited on 7 May 1987.

On 6 April 1988 C. Palmer and I observed two hybrid grouse with 33 male and 15 female Sage Grouse at this lek. Both of the hybrids were displaying and so presumed to be males. Although they were too far away to photograph, we did observe them through a spotting scope and recorded the following observations.

The birds had fan tails which appeared brown with black edgings and black tips. From the underside white spots showed on the tail fan. The tail feathers did not have the pronounced points of a Sage Grouse. The birds displayed with the head tilted forward and the tail up and spread, much as a Sharp-tailed Grouse would. However we did not record them actually strutting like Sharp-tailed Grouse. Wings and back were grayish brown. The breasts were white. A distinctive feature was a dark ruff of feathers across the chest which appeared to erect during display. This dark patch came half way down the chest.

When I observed the hybrid at Meyronne I was struck by the strong similarity of the three hybrids. Using this description and the photos included in Harris, Weidl \& McAdam ${ }^{2}$ I noted all three hybrids showed the dark ruff covering large air sacs, whitish breast and similar black fan tails tipped with white. From the back side, the tail of the hybrid photographed by Harris, Weidl \& McAdam ${ }^{2}$ showed more white than the Meyronne bird, but was otherwise similar.

There are three good field marks which easily separate Greater Prairie Chicken from Sharp-tailed Grouse in the field: These are the pinnae, short rounded dark tail, and heavily barred breast of the Greater Prairie Chicken compared to no pinnae, white pointed tail and white breast with $V$ markings on the Sharp-tailed Grouse. Close examination of the photographs showed no pinnae, although the erected ruff feathers gave the impression of pinnae, whitish breast and a dark tail. The first two suggest Sharp-tailed Grouse ancestry, the latter could indicate Greater Prairie Chicken ancestry, but could also come from the Sage Grouse. The white breast seems especially strong evidence of Sharp-tailed Grouse ancestry as of the three species, only the Sharp-tailed Grouse has a white breast. The North Dakota hybrid grouse, identified as Sharp-tailed/ Sage Grouse also had a whitish 
breast, dark ruff and dark fan tail. I therefore concluded that all three Saskatchewan hybrids were Sharptailed Grouse X Sage Grouse hybrids.

W. Harris observed a fourth hybrid grouse at a lek along Rock Creek on NW/12 TWP 1-6W3 in 1988. I also visited that lek 7 April 1988 and observed 46 male and 43 female Sage Grouse but I did not see the hybrid. $W$. Harris (pers. comm) indicated it was similar to the other hybrids. These two leks are less than four miles apart, so it is possible one hybrid had moved between the two leks.

In 1989 Wayne Harris observed one hybrid grouse at the Rock Creek lek, none were observed along Weatherald Creek or at Meyronne. I am not aware of any observations of these hybrids since 1989.

Was there a common factor causing this hybridization? First it is possible the two or three hybrids south of Glentworth were siblings, so there may be only 2 cases of hybridization. The Meyronne hybridization could be a result of the declining population, leaving a last Sage Grouse with no conspecific partners and therefore electing to mate with another species. However 93 male Sage Grouse and 44 male Sharp-tailed Grouse were counted in 1988 on TWP 1$6 \mathrm{~W} 3$, the township where the hybrids were observed. ${ }^{3}$ There should therefore have been suitable conspecific mates for both species. The occurrence of hybridization here at the same time as at Meyronne was probably just coincidence.

1. ENG, R.L. 1971. Two hybrid Sage Grouse X Sharp-tailed Grouse from Central Montana. Wilson Bull. 73: 491-493.

2. HARRIS, W.C, D.A. WEIDL and S.A. MCADAM. 1987. Rediscovery of Greater Prairie Chickens in southern Saskatchewan. Report by Prairie Environmental Services Inc., Raymore, Sask. 7 pp.

3. HJERTAAS, D. 1988. Saskatchewan's 1988 search for the Greater Prairie Chicken. Wildlife Population Management Information Base 88-19. Sask. Parks Recreation and Culture. 5 pp. plus tables.

4. KOHN, S.C and G.D KOBRIGER. 1986. Occurrence of a Sage Grouse/ Sharp-tailed Grouse hybrid in North Dakota. Prairie Nat. 18:33-36.

5. RENSEL, J.A. and C.M. WHITE. 1988. First description of a hybrid Blue X Sage Grouse. Condor 90:716717.



The forest at night is an experience in sensory deprivation most of the time, black and silent as the midnight zone of a cave. Life is out there in unexpected abundance. The jungle teems, but in a manner mostly beyond the reach of the human senses. Ninety-nine percent of the animals find their way by chemical trails laid over the surface, puffs of odor released into the air or water, and scents diffused out of little hidden glands and into the air downwind. Animals are masters of this chemical channel, where we are idiots. But we are geniuses of the audiovisual channel, equalled in this modality only by a few odd groups (whales, monkeys, birds). So we wait for dawn, while they wait for the fall of darkness; and because sight and sound are the evolutionary prerequisites of intelligence, we alone have come to reflect on such matters as Amazon nights and sensory modalities. E.O. Wilson. 1992. The diversity of life. W.W. Norton and Company, New York. 